\title{
Enhanced Hydrophilicity and Protein Adsorption of Titanium Surface by Sodium Bicarbonate Solution
}

\author{
Shengnan Jia, ${ }^{1}$ Yu Zhang, ${ }^{1}$ Ting Ma, ${ }^{1}$ Haifeng Chen, ${ }^{2}$ and Ye Lin' \\ ${ }^{1}$ Department of Implant Dentistry, School and Hospital of Stomatology, Peking University, Beijing 100081, China \\ ${ }^{2}$ Department of Biomedical Engineering, College of Engineering, Peking University, Beijing 100871, China \\ Correspondence should be addressed to Ye Lin; yorcklin@263.net
}

Received 27 August 2015; Accepted 21 October 2015

Academic Editor: Daniel S. Oh

Copyright (c) 2015 Shengnan Jia et al. This is an open access article distributed under the Creative Commons Attribution License, which permits unrestricted use, distribution, and reproduction in any medium, provided the original work is properly cited.

\begin{abstract}
The aim of this study was to investigate a novel and convenient method of chemical treatment to modify the hydrophilicity of titanium surfaces. Sand-blasted and acid-etched (SLA) titanium surfaces and machined titanium surfaces were treated with sodium bicarbonate $\left(\mathrm{NaHCO}_{3}\right)$ solution. The wetting behavior of both kinds of surfaces was measured by water contact angle (WCA) test. The surface microstructure was assessed with scanning electron microscopy (SEM) and three-dimensional (3D) optical microscopy. The elemental compositions of the surfaces were analyzed by X-ray photoelectron spectroscopy (XPS). The protein adsorption analysis was performed with fibronectin. Results showed that, after $1 \mathrm{M} \mathrm{NaHCO}_{3}$ treatment, the hydrophilicity of both SLA and machined surfaces was enhanced. No significant microstructural change presented on titanium surfaces after $\mathrm{NaHCO}_{3}$ treatment. The deprotonation and ion exchange activities might cause the enhanced hydrophilicity of titanium surfaces. The increased protein adsorption of $\mathrm{NaHCO}_{3}$-treated SLA surfaces might indicate their improved tissue-integration in clinical use.
\end{abstract}

\section{Introduction}

Titanium implant is widely used in dentistry because of its extraordinary biocompatibility and mechanical properties [1]. The tissue-integration of titanium surface plays a key role in the long-term clinical success. Different surface treatments that favor the bioactivity and bioconductivity of titanium implants have been investigated [2].

The interactions between titanium surface and host cells can be influenced by the surface characteristics of implants including topography, chemical properties, surface charge, and hydrophilicity [3]. The modification of Ti surfaces' topography is claimed to be influential to protein adsorption, osteoblast proliferation and differentiation, and tissueintegration [4].

Sand-blasted and acid-etched (SLA) Ti surface implants are widely used in clinical dental practice. This kind of surface is reported to have micro- and nanometer scale topography created by blasting and acid-etching processes. It was suggested that the topography of biomaterial surface in micro- or nanometer scale can promote higher cell-adhesion strengths [5].
Additionally, surface charge, surface energy, hydrophilicity, and other physicochemical properties of implant surfaces can also influence tissue-integration. In the last decade, interest in the hydrophilicity property of titanium surface has increased in both in vitro $[6,7]$ and in vivo $[7,8]$ studies. Most of these studies stated that hydrophilicity enhanced cell adhesion, proliferation and differentiation, and bone mineralization at an early stage $[9,10]$.

Hence, various techniques were attempted to increase the hydrophilicity of implant surfaces [11-14]. Nonetheless, these attempts of different techniques are argued to be either unpractical with high-standard technical requirements and rather long processing time or requiring severe chemical conditions, which, in clinical implantology, might probably impede the proposed application of the treated specimens.

Recently, a chemical treatment with $\mathrm{NaOH}$ has been reported to significantly improve the hydrophilicity of titanium surfaces $[15,16]$. Performed by soaking the Ti discs or implants in $0.05 \mathrm{M} \mathrm{NaOH}$ for $30 \mathrm{~s}$ at room temperature, this treatment was reported to support fast and homogenous protein adsorption and consecutive osseointegration [15, 17]. 
Furthermore, it was also stated that enhanced surface energy by $\mathrm{NaOH}$-induced hydrophilicity is responsible for the promotion of blood components adhesion [15] and cell adhesion to titanium surfaces [18]. $\mathrm{NaOH}$-treated Ti implants were demonstrated with stronger osseointegrative potential in vivo as well [19]. Stadlinger et al. tested $\mathrm{NaOH}$-treated and untreated implants in the mandible of an in vivo minipig model. By comparing the removal torque and interfacial stiffness, surfaces of $\mathrm{NaOH}$-treated implants exhibited a tendency to promote early peri-implant bone formation [20].

Sodium bicarbonate $\left(\mathrm{NaHCO}_{3}\right)$ solution is widely used as mouth-rinse in clinic for oral hygiene maintenance [21]. The aim of this study was to develop a mild alkali treatment method for preparing enhanced hydrophilic Ti implant surfaces. The experiment was designed for SLA and machined Ti implant surfaces to be treated with $1 \mathrm{M} \mathrm{NaHCO}_{3}$ solution. In this study, detailed physicochemical characterization of the $\mathrm{NaHCO}_{3}$-treated Ti surfaces is presented as key findings. The influences of surface roughness and surface chemistry on the hydrophilicity transformations of the specimens were also evaluated. This evaluation was performed by measuring changes in the physicochemical properties of the Ti specimens with respect to chemical surface treatment and surface roughness. Fibronectin adsorption ability on $\mathrm{NaHCO}_{3}-$ treated SLA Ti surfaces was also investigated by comparing with untreated SLA Ti surfaces.

\section{Materials and Methods}

2.1. Specimen Preparation. Two types of Ti discs were employed as experiment specimens, which were machined and SLA Ti discs (Wego Jericom Biomaterials Co., Weihai, China). Both kinds of the discs have a diameter of $15 \mathrm{~mm}$ and a thickness of $1 \mathrm{~mm}$. Machined Ti discs were made of commercially pure titanium that conformed with ISO 5832-2 grade 4 by milling process. As stated in the previous study [22], SLA discs were produced by sand-blasting machined Ti discs with $\mathrm{Al}_{2} \mathrm{O}_{3}$ particles (particle size 250-500 $\mu \mathrm{m}$ ) and then acid-etching the specimens in a boiling mixture of hydrochloric and sulphuric acid. Both discs were treated in nitric acid, deionised water, and air in sequence for them to be cleaned, rinsed, and dried correspondingly. At last, discs were stored in aluminum foil.

2.2. $\mathrm{NaHCO}_{3}$ Solution Treatment. $\mathrm{NaHCO}_{3}$ solution treatment was performed at room temperature. The SLA and machined Ti discs were assigned into three groups according to the difference in their chemical states, which were untreated (i.e., "untreated" group), treated with $1 \mathrm{M} \mathrm{NaHCO}_{3}$ solution (i.e., " $\mathrm{NaHCO}_{3}$-treated" group), and treated with $1 \mathrm{M}$ $\mathrm{NaHCO}_{3}$ solution and rinsed with Milli-Q water (Milli-Q Advantage, Millipore, France) for three times (i.e., "rinsed" group). Specimens in the untreated group maintain their original properties for further comparison. All specimens were then blow-dried in a nitrogen stream shortly before being measured.

2.3. Surface Hydrophilicity Assessment. The hydrophilicity of SLA and machined $\mathrm{Ti}$ discs in the untreated,
$\mathrm{NaHCO}_{3}$-treated and rinsed group was examined both quantitatively and qualitatively by water contact angle (WCA) test, which is formed by a $10 \mu \mathrm{L}$ drop of distilled water on the $\mathrm{Ti}$ surfaces. The measurement was performed by a contact angle system (OCA20, Dataphysics, Germany). All of the WCA data were obtained by ellipse methods. In this measurement process, specimens from both $\mathrm{NaHCO}_{3}$-treated and rinsed group were further divided into 4 subgroups, each being soaked in $\mathrm{NaHCO}_{3}$ solution for $30 \mathrm{~s}, 1 \mathrm{~min}, 3 \mathrm{~min}$, or $5 \mathrm{~min}$, respectively. The average WCAs of the 4 samples in each subgroup were evaluated and then compared with each other and the ones in the untreated group. The subgroups were set up in order to observe the effects of soaking time on wetting behavior.

2.4. Surface Microstructure Characterization. In order to observe the microstructure of SLA and machined discs and to analyze what influences $\mathrm{NaHCO}_{3}$ treatment had on materials' topography change, a scanning electron microscope (SEM) (S-3000N, Hitachi, Japan) and a three-dimensional (3D) optical microscope (Contour GT, Bruker, US) were utilized to analyze the specimens before and after a $3 \mathrm{~min} \mathrm{NaHCO}_{3}$ treatment. A period of 3 minutes can be a suitable treatment time according to the results of the hydrophilicity assessment experiment (see Section 3.1 for details).

The SEM scanned specimens coated with gold at $15.0 \mathrm{kV}$ and a magnification of 2000x. Surface roughness data and $3 \mathrm{D}$ images of the specimens were acquired by the $3 \mathrm{D}$ optical microscopy. Roughness data were then analyzed with Vision64 software. Four specimens from each group were evaluated by observing four random spots on each of them. The average values of their roughness average $\left(R_{a}\right)$, maximum peak height $\left(R_{p}\right)$, root mean square roughness $\left(R_{q}\right)$, and maximum height of the profile $\left(R_{t}\right)$ were hence calculated.

2.5. Surfaces' Elemental Composition. An X-ray photoelectron spectroscopy (XPS) (ESCALAB $250 \mathrm{Xi}$, Thermo Scientific, US) that uses monochromatic $\mathrm{AlK}_{\alpha}$ radiation was employed to analyze surface elemental composition of the SLA specimens in three groups. Survey (wide-scan) spectra were recorded with a pass energy level of $100 \mathrm{eV}$ and a resolution of $1.000 \mathrm{eV}$, while high-resolution (narrow-scan) spectra were obtained with a pass energy level of $30 \mathrm{eV}$ and a resolution of $0.050 \mathrm{eV}$ for $\mathrm{C} 1$ and $\mathrm{O} 1$. In each specimen group, three discs were tested. According to the methods suggested by McCafferty and Wightman, peak attribution and selection of full width at half maximum values were then executed to fit the high-resolution spectra [23]. All binding energies were checked in reference to the carbon $\mathrm{C}-\mathrm{H}$ photopeak at $285.0 \mathrm{eV}$. High-resolution spectra for $\mathrm{C} 1$ and $\mathrm{O} 1$ were further analyzed using XPSPEAK 4.1 software.

2.6. Protein Adsorption. SLA specimens in both untreated and $\mathrm{NaHCO}_{3}$-treated groups participated in this section. The $\mathrm{NaHCO}_{3}$-treated specimens were immersed in the solution for $3 \mathrm{~min}$. The treated specimens were carefully cleaned by a lint-free cleaning wipe to remove any residual solution and then blow-dried in a nitrogen stream. 
TABLE 1: WCAs $\left({ }^{\circ}\right)$ after different treatment time for both SLA and machined specimens from three test groups: untreated, $\mathrm{NaHCO}_{3}$-treated, and rinsed $(n=4$, mean $\pm \mathrm{SD})$.

\begin{tabular}{|c|c|c|c|c|c|c|c|c|c|}
\hline & \multirow{2}{*}{ Untreated } & \multicolumn{4}{|c|}{$\mathrm{NaHCO}_{3}$-treated } & \multicolumn{4}{|c|}{ Rinsed } \\
\hline & & $30 \mathrm{~s}$ & $1 \mathrm{~min}$ & $3 \mathrm{~min}$ & $5 \min$ & $30 \mathrm{~s}$ & $1 \mathrm{~min}$ & $3 \min$ & $5 \mathrm{~min}$ \\
\hline SLA & $129.9 \pm 7.1$ & $17.6 \pm 4.5$ & $0.0 \pm 0.0$ & $0.0 \pm 0.0$ & $0.0 \pm 0.0$ & $63.0 \pm 5.9$ & $3.3 \pm 4.0$ & $2.0 \pm 4.0$ & $0.0 \pm 0.0$ \\
\hline Machined & $86.0 \pm 6.7$ & $55.0 \pm 11.4$ & $45.3 \pm 7.1$ & $37.5 \pm 3.4$ & $34.4 \pm 12.5$ & $81.4 \pm 7.2$ & $59.1 \pm 17.7$ & $53.1 \pm 19.1$ & $52.9 \pm 18.1$ \\
\hline
\end{tabular}

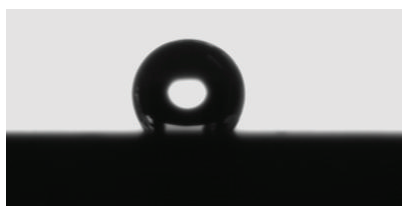

(a)

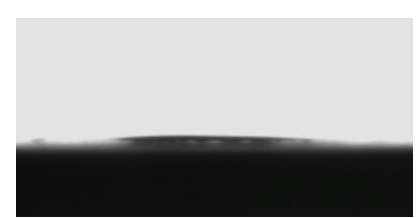

(b)

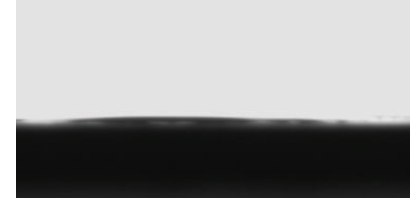

(c)

FIgURE 1: Image of a $10 \mu \mathrm{L}$ distilled water drop on (a) untreated, (b) $\mathrm{NaHCO}_{3}$-treated (3 min), and (c) rinsed SLA discs. Untreated SLA disc (a) was hydrophobic, while $\mathrm{NaHCO}_{3}$-treated SLA disc (b) was superhydrophilic as the observed WCA was close to 0. Rinsed SLA disc (c) maintained superhydrophilicity.

$1 \mu \mathrm{M}$ fibronectin (HiLyte Fluor 488 labeled) solution was prepared in $20 \mathrm{mM} \mathrm{NaCl}$-buffer according to the instructions from HiLyte and was then directly applied in the experiments. Protein adsorption tests were executed with sandwich assay. $10 \mu \mathrm{L}$ of the protein solution was incubated between an SLA disk and a round-shaped microscopy glass cover slip with a diameter of $12 \mathrm{~mm}$ for $5 \mathrm{~min}$. The process was carried out in a dark environment with saturated humidity at room temperature. Afterwards, the specimens were rinsed with $20 \mathrm{mM}$ $\mathrm{NaCl}$-buffer for 3 times ( $5 \mathrm{~min}$ each time) to remove loosely bound fibronectin on the SLA surfaces. Finally, specimens were analyzed using a confocal microscopy (LSM710, Zeiss, Germany) with an excitation wavelength of $488 \mathrm{~nm}$ and a cut of filter of 505-550 $\mathrm{nm}$ for detection. The adsorption of protein on the specimens was evaluated by measuring relative fluorescence intensity with the help from ImageJ (NIH, Bethesda, MD, USA) software.

2.7. Statistical Analysis. All data presented in this study are expressed as "mean \pm standard deviation (SD)." Data were subjected to an independent samples $t$-test or one-way ANOVA using SPSS 22.0 software for Mac. For analysis in this paper, significant differences were ones with a $P<0.05$.

\section{Results}

3.1. Surface Hydrophilicity Assessment. The effects of surface energy changes were analyzed by measuring the WCAs on SLA and machined $\mathrm{Ti}$ surfaces. The rinsed group was arranged to clarify if the increased hydrophilicity of $\mathrm{NaHCO}_{3}$-treated specimens was just temporary because of the adhesion of $\mathrm{Na}^{+}$and negative ions $\left(\mathrm{OH}^{-}, \mathrm{HCO}_{3}{ }^{-}, \mathrm{CO}_{3}{ }^{2-}\right.$, etc.) on the specimen surfaces.

Figure 1 shows the WCAs of SLA surfaces under three states: untreated, $\mathrm{NaHCO}_{3}$-treated for $3 \mathrm{~min}$, and rinsed. According to Figure 1, the WCA of untreated SLA disc was obtuse. After $\mathrm{NaHCO}_{3}$ treatment, WCA was nearly 0 . This angle was maintained after the disc being rinsed. Table 1 and

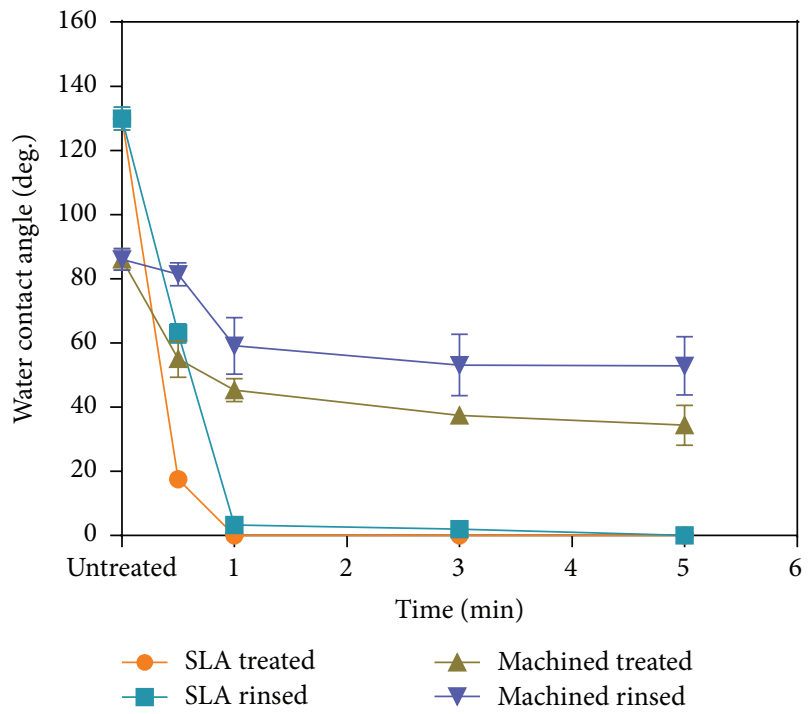

Figure 2: A plot of WCA $\left({ }^{\circ}\right)$ on both SLA and machined specimens $\mathrm{NaHCO}_{3}$-treated at different time points with or without being rinsed. The WCAs of both SLA and machined specimens decreased with increasing treatment time. The WCAs of SLA specimens showed rapid decline. After $1 \mathrm{~min}$, the WCAs of the $\mathrm{NaHCO}_{3}$ treated and rinsed SLA specimens decreased to almost zero. The WCAs of machined surfaces displayed a relatively small decrement after $\mathrm{NaHCO}_{3}$ treatment and a slight increment after being rinsed.

Figure 2 show the WCAs of the SLA and machined specimens from three test groups with different chemical states. As evidenced by Table 1, the WCAs of untreated Ti specimens increased from $86^{\circ}$ on the smooth machined surfaces to $130^{\circ}$ on the SLA specimens. Therefore, untreated SLA specimens could be classified as hydrophobic. Also, it could be seen that the WCAs of both SLA and machined specimens decreased with increasing treatment time. However, while the machined surfaces had only displayed a relatively small decrement, data of SLA surfaces showed rapid decline, for a treatment time 
TABLE 2: WCAs of SLA and machined specimens from three test groups, $0,10,30,60$, and 120 min of exposure in the air ( $n=4$, mean \pm SD).

\begin{tabular}{|c|c|c|c|c|c|}
\hline Modification & $0 \mathrm{~min}$ & $10 \mathrm{~min}$ & $30 \mathrm{~min}$ & $60 \mathrm{~min}$ & $120 \mathrm{~min}$ \\
\hline $\mathrm{SLA} \mathrm{NaHCO}_{3}$-treated & $0.0 \pm 0.0$ & $0.0 \pm 0.0$ & $22.0 \pm 10.6$ & $47.6 \pm 9.5$ & $54.4 \pm 10.4$ \\
\hline SLA rinsed & $2.0 \pm 4.0$ & $2.9 \pm 5.8$ & $15.0 \pm 6.8$ & $50.1 \pm 9.6$ & $53.0 \pm 14.6$ \\
\hline Machined $\mathrm{NaHCO}_{3}$-treated & $37.5 \pm 3.4$ & $41.4 \pm 3.7$ & $45.7 \pm 11.6$ & $56.2 \pm 13.3$ & $56.9 \pm 9.2$ \\
\hline Machined rinsed & $53.1 \pm 19.1$ & $52.5 \pm 12.0$ & $55.9 \pm 11.1$ & $56.3 \pm 10.7$ & $55.6 \pm 18.3$ \\
\hline
\end{tabular}

TABLE 3: Roughness measurements of the untreated and $\mathrm{NaHCO}_{3}$-treated machined and SLA surfaces (mean $\left.\pm \mathrm{SD}, n=4, \mu \mathrm{m}\right)$.

\begin{tabular}{|c|c|c|c|c|c|c|c|c|}
\hline \multirow{2}{*}{ Modification } & \multicolumn{4}{|c|}{ Machined } & \multicolumn{4}{|c|}{ SLA } \\
\hline & $R_{a}$ & $R_{p}$ & $R_{q}$ & $R_{t}$ & $R_{a}$ & $R_{p}$ & $R_{q}$ & $R_{t}$ \\
\hline Untreated & $0.15 \pm 0.02$ & $1.37 \pm 0.19$ & $0.20 \pm 0.02$ & $2.39 \pm 0.29$ & $2.04 \pm 0.16$ & $9.16 \pm 1.33$ & $2.58 \pm 0.18$ & $21.91 \pm 3.55$ \\
\hline $\mathrm{NaHCO}_{3}$-treated & $0.14 \pm 0.02$ & $1.27 \pm 0.15$ & $0.19 \pm 0.02$ & $2.48 \pm 0.26$ & $2.09 \pm 0.14$ & $9.96 \pm 1.66$ & $2.65 \pm 0.16$ & $23.38 \pm 3.57$ \\
\hline$P$ values & 0.108 & 0.123 & 0.258 & 0.356 & 0.335 & 0.145 & 0.264 & 0.249 \\
\hline
\end{tabular}

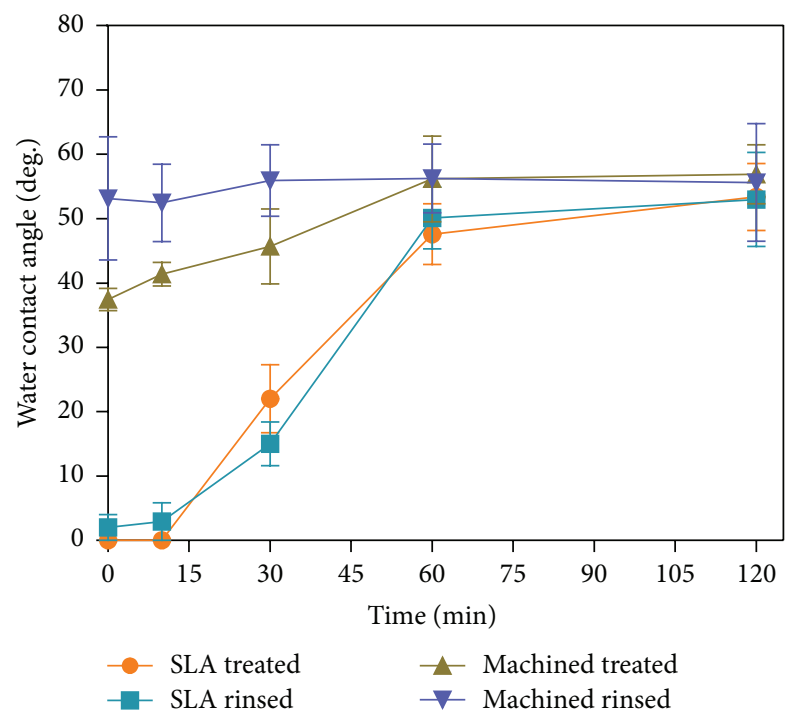

FIgURE 3: Plot of WCA $\left({ }^{\circ}\right)$ on SLA and machined specimens from both the $\mathrm{NaHCO}_{3}$-treated and rinsed groups after different time exposed in the air. The value of WCAs increased with longer exposure time.

more than $1 \mathrm{~min}$, and the WCAs of the $\mathrm{NaHCO}_{3}$-treated SLA specimens were recorded to be extremely close to zero. This change in hydrophilicity upon $\mathrm{NaHCO}_{3}$ treatment shifted the SLA specimens from hydrophobic to superhydrophilic. Also, notice that by comparing the $\mathrm{NaHCO}_{3}$-treated and rinsed groups, it could be argued that the superhydrophilicity of $\mathrm{NaHCO}_{3}$-treated SLA specimens could be fully preserved after rinsing.

After 3 minutes of $\mathrm{NaHCO}_{3}$ treatment and rinsing, the SLA and machined specimens were exposed in the air for $120 \mathrm{~min}$, within which WCAs were measured again at different time points. Table 2 and Figure 3 show that the value of WCAs increased with longer exposure time. From the shown data, it can be concluded that the SLA specimens can remain superhydrophilic for at least $10 \mathrm{~min}$.
3.2. Surface Microstructure Characterization. The SEM micrograph in Figure 4(a) illustrates the complex microstructure of an untreated SLA surface. Sand-blasting and acid-etching produced cavities and micropits were observed. Moreover, Figure 4(c) displays the profile of an untreated machined surface that exhibits less roughness. By comparing the SEM results of the untreated surfaces (Figures 4(a) and $4(\mathrm{c})$ ) and the $\mathrm{NaHCO}_{3}$-treated surfaces (Figures 4(b) and $4(\mathrm{~d})$ ), it can be seen that both the SLA and machined $\mathrm{Ti}$ surfaces experienced no significant morphological differences before and after the $\mathrm{NaHCO}_{3}$ treatment.

The 3D images in Figure 5 and the roughness data in Table 3 were both output from the 3D optical microscopy. 3D images display no apparent discrepancy between the untreated and $\mathrm{NaHCO}_{3}$-treated surfaces of both SLA and machined specimens. Similarly, the roughness measurements of the two surfaces before and after 3 min $\mathrm{NaHCO}_{3}$ treatment in Table 3 demonstrate a more quantifiable version of this statement. A comparison can be made by observing Table 3 . Mean $R_{a}$ was $0.15 \mu \mathrm{m}$ for the untreated machined surfaces and $0.14 \mu \mathrm{m}$ for the $\mathrm{NaHCO}_{3}$-treated ones, while for the SLA surfaces mean $R_{a}$ was $2.04 \mu \mathrm{m}$ before the treatment and $2.09 \mu \mathrm{m}$ after it. $P$ values for both surfaces are larger than 0.05 . Therefore, a conclusion can be reached that being treated with $\mathrm{NaHCO}_{3}$ solution does not produce significant difference in the roughness of both machined and SLA specimens.

3.3. Surface Elemental Composition Analysis. Utilizing the XPS software, initially, the survey spectra were analyzed. Figures 6(a), 6(b), and 6(c) show the survey spectra of untreated, $\mathrm{NaHCO}_{3}$-treated, and rinsed SLA Ti surfaces, respectively. According to Figure 6(a), the survey spectra of the untreated SLA specimens consist of titanium (Ti), oxygen $(\mathrm{O})$, and carbon (C) as main elements. While it is apparent in Figure 6(b) that, after $\mathrm{NaHCO}_{3}$ treatment, sodium (Na) signal was detected as another main element, the other three main elements, $\mathrm{O}, \mathrm{C}$ and $\mathrm{Ti}$, all had a change in their substance amount rate (counts/s). However, Figure 6(c) does not 


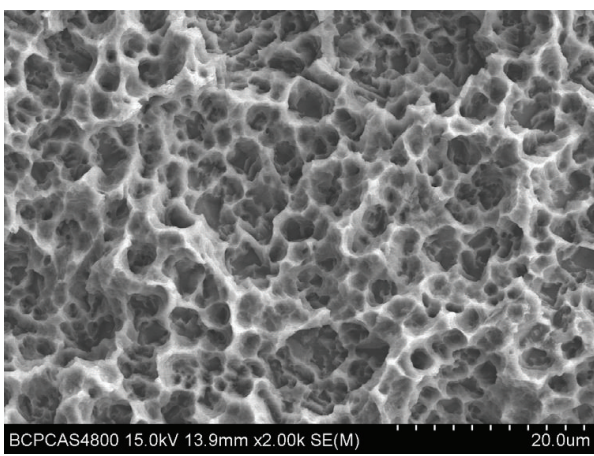

(a)

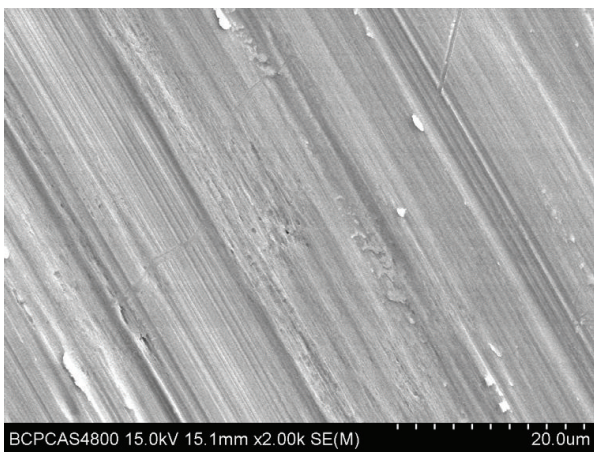

(c)

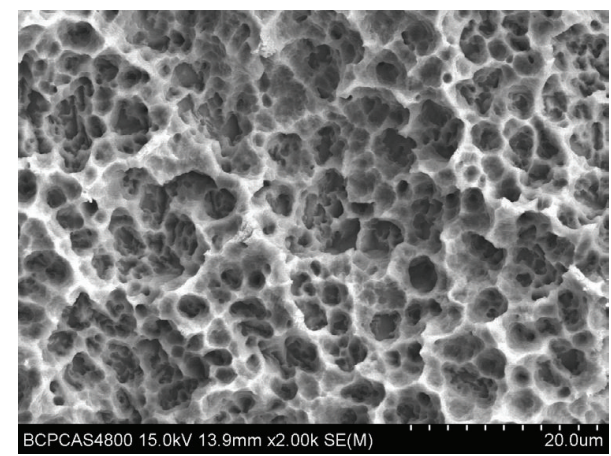

(b)

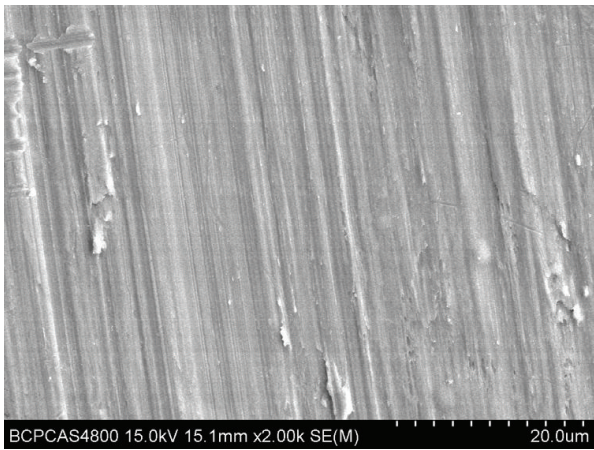

(d)

FIGURE 4: SEM of an SLA and a machined Ti surface in different chemical states: untreated SLA surface (a), $\mathrm{NaHCO}_{3}$-treated SLA surface (b), untreated machined surface (c), and $\mathrm{NaHCO}_{3}$-treated machined surface (d). (a) The microrough structure of an untreated SLA surface caused by sand-blasting and acid-etching and (b) the microstructure of the smooth surface of a machined Ti disc. By comparing the SEM results in $(a, b)$ and $(c, d)$, no significant morphological change of SLA and machined Ti surfaces could be observed before and after the $\mathrm{NaHCO}_{3}$ treatment.

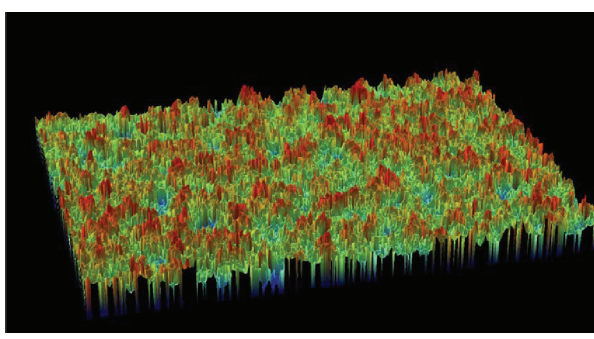

(a)

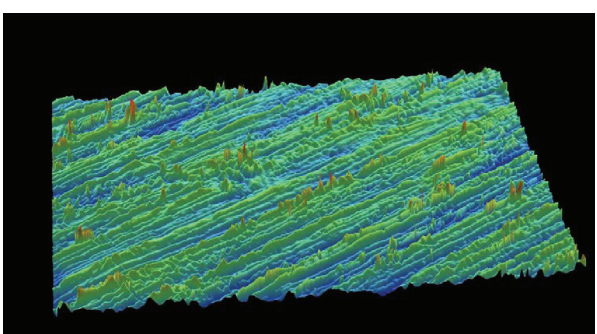

(c)

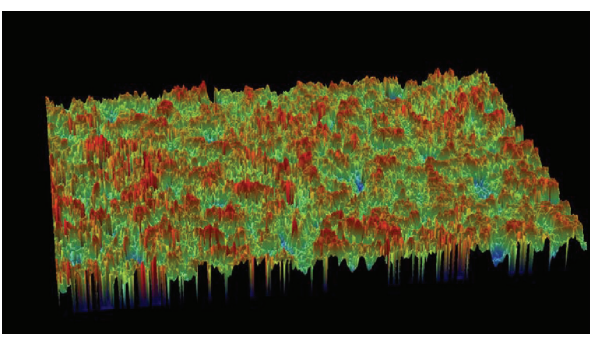

(b)

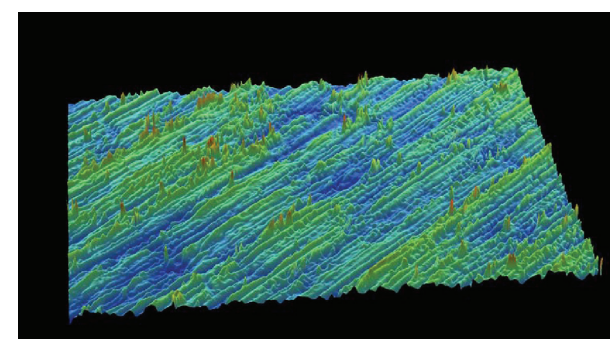

(d)

FIGURE 5: 3D images of an SLA and a machined surface generated by 3D optical microscopy in different chemical states: untreated SLA surface (a), $\mathrm{NaHCO}_{3}$-treated SLA surface (b), untreated machined surface (c), and $\mathrm{NaHCO}_{3}$-treated machined surface (d). 


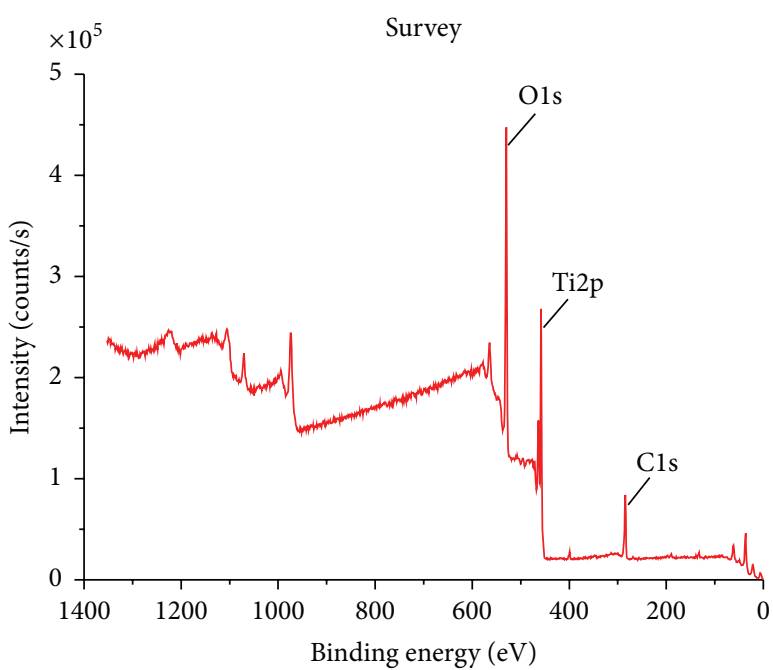

(a)

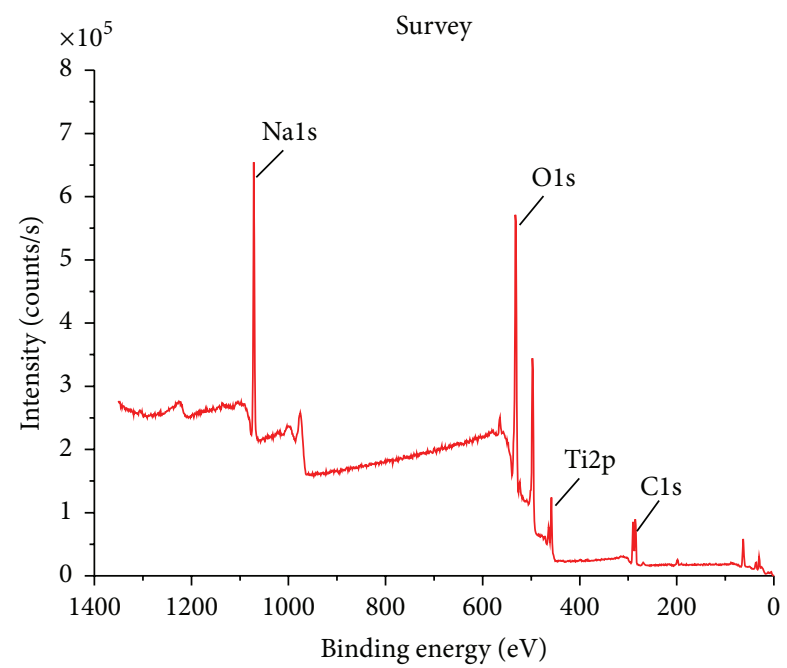

(b)

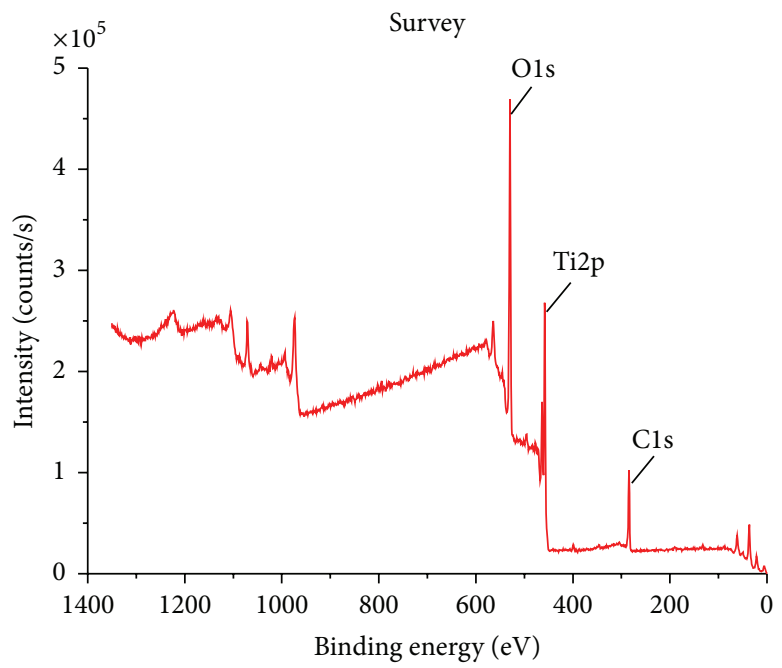

(c)

Figure 6: Survey spectra of untreated (a), $\mathrm{NaHCO}_{3}$-treated (b), and rinsed (c) SLA specimens. (a) Titanium (Ti), oxygen (O), and carbon (C) were the main elements of untreated SLA specimens. From (b), sodium ( $\mathrm{Na}$ ) was detected as another main element on the tested specimens after $\mathrm{NaHCO}_{3}$ treatment. Compared with (a), (c) does not reflect any significant differences in elemental composition.

TABLE 4: Relative elemental compositions of untreated, $\mathrm{NaHCO}_{3}$-treated, and rinsed SLA specimens, obtained from the survey spectra (\%).

\begin{tabular}{lcccc}
\hline Modification & $\mathrm{C}$ & $\mathrm{Ti}$ & $\mathrm{O}$ & $\mathrm{Na}$ \\
\hline Untreated & $33.2 \pm 3.9 \%$ & $19.4 \pm 1.8 \%$ & $47.2 \pm 2.1 \%$ & n.d. \\
$\mathrm{NaHCO}_{3}$-treated & $25.2 \pm 1.9 \%$ & $2.7 \pm 2.3 \%$ & $51.4 \pm 1.5 \%$ & $20.7 \pm 3.2 \%$ \\
Rinsed & $35.0 \pm 5.8 \%$ & $17.4 \pm 3.6 \%$ & $43.8 \pm 3.2 \%$ & $3.9 \pm 1.5 \%$ \\
\hline
\end{tabular}

reflect any significant differences in elemental composition between data of the untreated and rinsed groups. Based on the survey spectra, detailed elemental compositions of the surfaces are derived and recorded in Tables 4, 5, and 6.

Table 4 represents the relative elemental compositions of three SLA surfaces groups. It was shown that the untreated group displayed an $\mathrm{O} / \mathrm{C}$ ratio of 1.42 and a relative $\mathrm{C}$ content
TABLE 5: Relative elemental contributions to the C1s signal for untreated, $\mathrm{NaHCO}_{3}$-treated, and rinsed SLA Ti specimens.

\begin{tabular}{lccc}
\hline Modification & $\mathrm{C}-\mathrm{C}$ & $\mathrm{CO}$ & $\mathrm{CO}_{2} \& \mathrm{CO}_{3}$ \\
\hline Untreated & $75.4 \pm 5.3 \%$ & $16.4 \pm 4.6 \%$ & $9.1 \pm 1.5 \%$ \\
$\mathrm{NaHCO}_{3}$-treated & $42.5 \pm 10.5 \%$ & $9.5 \pm 1.0 \%$ & $48.0 \pm 10.8 \%$ \\
Rinsed & $77.5 \pm 1.9 \%$ & $16.7 \pm 0.7 \%$ & $5.9 \pm 1.9 \%$ \\
\hline
\end{tabular}


TABLE 6: Relative elemental contributions to the O1s signal for untreated, $\mathrm{NaHCO}_{3}$-treated, and rinsed SLA Ti specimens.

\begin{tabular}{lcccc}
\hline Modification & $\mathrm{TiO}$ & $\mathrm{C}-\mathrm{O}-\mathrm{C}$ & $\mathrm{OH}$ & $\mathrm{CO}_{x} / \mathrm{H}_{2} \mathrm{O}$ \\
\hline Untreated & $69.7 \pm 5.6 \%$ & $9.3 \pm 3.5 \%$ & $18.0 \pm 1.9 \%$ & $2.9 \pm 0.9 \%$ \\
$\mathrm{NaHCO}_{3}$-treated & $20.1 \pm 8.0 \%$ & $17.0 \pm 7.1 \%$ & $45.2 \pm 7.4 \%$ & $17.7 \pm 2.8 \%$ \\
Rinsed & $76.0 \pm 7.7 \%$ & $9.5 \pm 8.3 \%$ & $11.3 \pm 3.8 \%$ & $3.2 \pm 1.1 \%$ \\
\hline
\end{tabular}

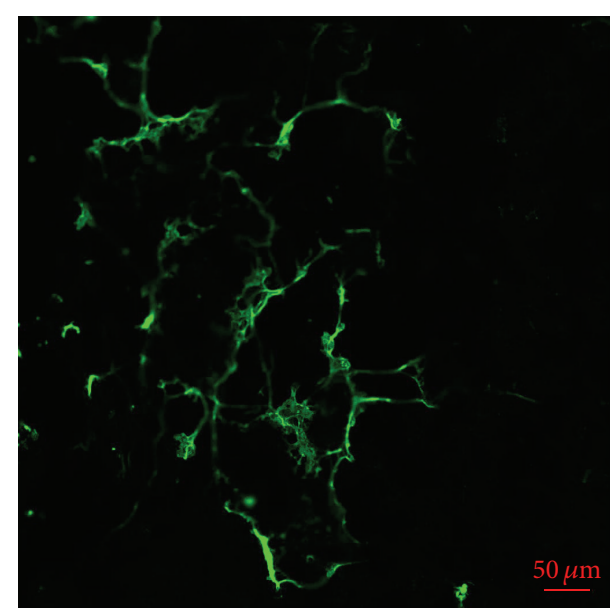

(a)

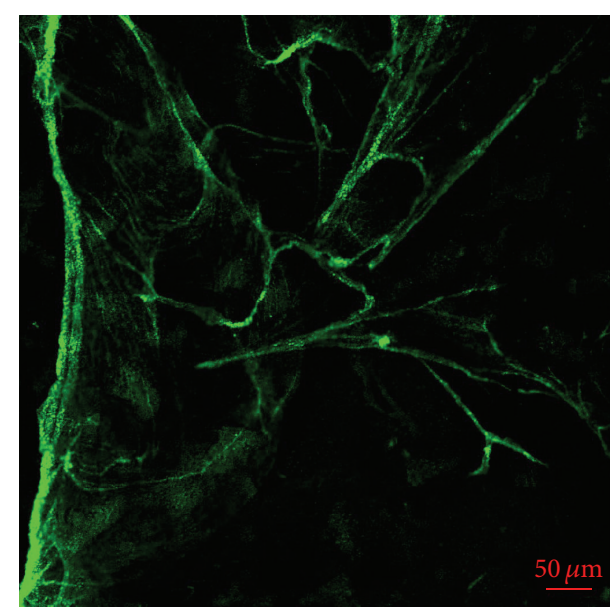

(b)

FIGURE 7: Fluorescence micrograph of untreated (a) and $\mathrm{NaHCO}_{3}$-treated (b) SLA Ti discs after incubation in a $1 \mu \mathrm{M}$ fibronectin for 5 min and subsequent washing steps. A larger amount of more uniformly distributed protein is showed in (b).

of $33.2 \%$. After the $\mathrm{NaHCO}_{3}$ treatment, the proportion of $\mathrm{C}$ content had decreased to $25.2 \%$ and the $\mathrm{O} / \mathrm{C}$ ratio had increased to 2.04 as the proportion of $\mathrm{O}$ content had an increase of $4 \%$. Data from the rinsed group showed no statistical difference compared to the ones from the untreated group.

C1s signals were considered to be contributed by aliphatic (C-C), ether and alcohol bound (CO), and carboxylate and carbonate bound $\left(\mathrm{CO}_{2}\right.$ and $\left.\mathrm{CO}_{3}\right) \mathrm{C}$. After these contributors were allocated, their contribution to the total $\mathrm{C}$ substance amount was derived and presented in Table 5. On the untreated SLA specimens, $75.4 \%$ of total C content was contributed by aliphatic, $16.4 \%$ by $\mathrm{CO}$ bound, and $9.1 \%$ by $\mathrm{CO}_{2}$ or $\mathrm{CO}_{3}$ bound $\mathrm{C}$. In contrast, these data had, respectively, become $42.5 \%$ by aliphatic, $9.5 \%$ by $\mathrm{CO}$ bound, and $48.0 \%$ by $\mathrm{CO}_{2}$ and $\mathrm{CO}_{3}$ bound $\mathrm{C}$ after the $\mathrm{NaHCO}_{3}$ treatment, demonstrating decrements in aliphatic, ether, and alcohol bound $\mathrm{C}$ but increments in $\mathrm{CO}_{2}$ and $\mathrm{CO}_{3}$ bound $\mathrm{C}$. Data from the rinsed group and the untreated group again showed similarity.

On the other hand, O1s signals were provided by Ti bound $\mathrm{O}^{2-}(\mathrm{TiO})$, oxygen bound to multiple carbon atoms (C-OC), $\mathrm{TiO}_{2-x}$ bound $\mathrm{OH}$ and $\mathrm{OH}^{-}$ions $(\mathrm{OH})$, and also oxygen atoms multiple-bound to carbon and $\mathrm{H}_{2} \mathrm{O}\left(\mathrm{CO}_{x} / \mathrm{H}_{2} \mathrm{O}\right)$. Notice that contributions from $\mathrm{CO}_{x}$ and $\mathrm{H}_{2} \mathrm{O}$ were unable to be measured individually. Table 6 shows that $69.7 \% \mathrm{TiO}_{2-x}$ bound, 9.3\% CO bound, $18.0 \% \mathrm{OH}$ bound, and $2.9 \% \mathrm{CO}_{x}$ bound $\mathrm{O}$ were detected on the untreated SLA specimens while after the $\mathrm{NaHCO}_{3}$ treatment, $20.1 \% \mathrm{TiO}_{2-x}$ bound,
$17.0 \% \mathrm{CO}$ bound, $45.2 \% \mathrm{OH}$ bound, and $17.7 \% \mathrm{CO}_{x}$ bound $\mathrm{O}$ were recorded. In a word, the contribution from $\mathrm{TiO}_{2-x}$ bound $\mathrm{O}$ was decreasing and, meanwhile, increments were discovered in the contribution of $\mathrm{CO}$ bound, $\mathrm{OH}$ bound, and $\mathrm{CO}_{x}$ bound $\mathrm{O}$.

3.4. Protein Adsorption. The differences of protein adsorption between untreated and $\mathrm{NaHCO}_{3}$-treated SLA Ti discs are showed in Figures 7 and 8. Figure 7 shows the fluorescence micrograph of the untreated and $\mathrm{NaHCO}_{3}$-treated SLA Ti discs after incubation in a $1 \mu \mathrm{M}$ fibronectin for $5 \mathrm{~min}$ and subsequent washing steps. More protein adsorption was found in $\mathrm{NaHCO}_{3}$-treated SLA Ti disc compared to untreated group. Moreover, the protein adsorbed on $\mathrm{NaHCO}_{3}$-treated SLA disc was well-distributed. Fluorescence intensity can represent the relative amount of proteins adsorbed on $\mathrm{Ti}$ discs. From Figure 8, the fluorescence intensity of $\mathrm{NaHCO}_{3}$ treated SLA Ti discs was stronger than that of untreated group (mean fluorescence intensity of 0.122 compared with 0.065 , resp.; $P=0.012$ ).

\section{Discussion}

4.1. Influence of Superhydrophilicity on Osseointegration. Titanium surfaces with WCA above $90^{\circ}$ are considered as hydrophobic. On the contrary, WCAs lower than $90^{\circ}$ categorize surfaces as hydrophilic, while WCAs too small to be almost neglected describe surfaces as having a superhydrophilic attribute [3]. As stated above, after $3 \mathrm{~min}$ of 


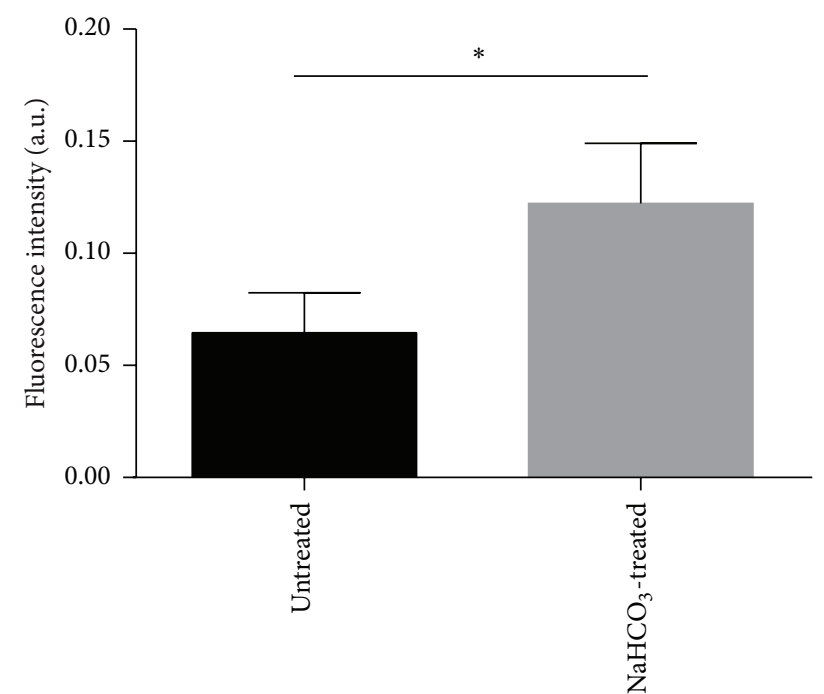

FIGURE 8: Average fluorescence intensity (a.u.) of adsorbed fibronectin on untreated and $\mathrm{NaHCO}_{3}$-treated SLA Ti surfaces. Fluorescence intensity of $\mathrm{NaHCO}_{3}$-treated SLA Ti discs was stronger than that of untreated group.

$\mathrm{NaHCO}_{3}$ treatment, the WCAs of SLA discs were nearly $0^{\circ}$ in this study, which subsequently transformed the material surface into superhydrophilic state.

Dental implants can be benefited by enhanced hydrophilic characteristic of surfaces due to better osseointegration performance. Ti implants with superhydrophilic surfaces were examined to have superb osseointegrative potential and raised much attention recently [24]. Early phases of osseointegration require osteogenic cells to primarily adhere to the implant surfaces and to further proliferate and differentiate into mature osteoblasts [25]. Hydrophilic surfaces support this process by promoting titanium to interact with cells, biological fluids, and tissues [8, 26]. For instance, cluster formation of osteoblasts as well as the expression of osteogenic genes can be enhanced by hydrophilic surfaces [17, 25, 27]. Superhydrophilic implants can optimize the osseointegration even more as they have proved useful to magnifying the area of bone-to-implant contact and strengthen mechanical fixation in the early healing processes of at least the first 4 weeks after implantation [8]. In this study, the $\mathrm{NaHCO}_{3}$ treated SLA discs had developed superhydrophilicity and been able to maintain it for $10 \mathrm{~min}$. This characteristic indicates that, to apply $\mathrm{NaHCO}_{3}$ treatment to the implants in clinic, there should be adequate time for clinicians to insert implants.

4.2. Regime Behind the Development of Superhydrophilicity. Wennerberg and Albrektsson stated that surfaces with smooth $\left(S_{a}<0.5 \mu \mathrm{m}\right)$ and minimal roughness $\left(S_{a} 0.5-1 \mu \mathrm{m}\right)$ showed less strong bone responses than surfaces with higher roughness. Meanwhile, surfaces with moderate roughness $\left(S_{a}\right.$ 1-2 $\mu \mathrm{m}$ ) showed stronger bone responses than surfaces with high roughness $\left(S_{a}>2 \mu \mathrm{m}\right)$ in some studies [28]. In the presented experiment, $R_{a}$ values were calculated for both SLA and machined surfaces to attempt to discover potential influences of surface topography on hydrophilicity. The SLA surfaces showed a mean $R_{a}$ value of about $2 \mu \mathrm{m}$, which should be considered to be moderately rough.

It was claimed that microrough Ti surfaces induce more advanced initial hydrophobicity compared with Ti surfaces without microroughness [29]. The same results were discovered in this study. The mean WCAs of untreated SLA and machined specimens were $130^{\circ}$ and $86^{\circ}$. On the other hand, on microrough titanium implant surfaces, which were not treated with any alkali, high WCAs are most likely to be caused by air entrapped in the micropores underneath the water droplets, according to the Cassie-Baxter regime [3]. However, for alkali treated microrough Ti specimens, the wetting behaviors were assumed by Tugulu et al. to be caused by a film regime [16]. The cavities of the microrough $\mathrm{Ti}$ specimens are supposed to be filled with wetting liquid due to capillary forces. Thus, this film regime is believed to be able to explain the low WCAs on $\mathrm{NaHCO}_{3}$-treated and rinsed SLA specimens.

Moreover, without any specific storage conditions, a thin passivation layer of $\mathrm{TiO}_{2-x}$ is formed on untreated native $\mathrm{Ti}$ surfaces. However, this $\mathrm{TiO}_{2-x}$ layer is observed to be rapidly contaminated by the hydrocarbons adsorption from the environment, which result in the hydrophobicity of Ti specimens and the repelling behaviors to water or biological fluids from tissues. The adsorption of hydrocarbons is considered to be able to change the osseointegrative potential of $\mathrm{Ti}$ implants $[8,11,26]$. Attempting to prevent this contamination, Rupp et al. have discovered that storing freshly prepared SLA Ti specimens in sodium chloride solution could significantly reduce the carbon contents on these superhydrophilic specimens to as low as $15 \%$, while $35 \%$ of carbon was recorded on the hydrophobic SLA specimens which was stored normally [11]. The findings from these reports agree with the XPS results shown in this study. The reduction of carbon contents on $\mathrm{NaHCO}_{3}$-treated SLA surfaces may be regarded as a possible cause to explain the obtained hydrophilicity of $\mathrm{NaHCO}_{3}$ treated SLA Ti surfaces. However, this regime can yet explain the increased hydrophilicity of the rinsed group specimens whose carbon contents were at a rather high level with no difference with the untreated group.

According to high-resolution O1s signal of the $\mathrm{NaHCO}_{3}$ treated $\mathrm{Ti}$ specimens, $\mathrm{TiO}_{2-x}$ bound $\mathrm{OH}$ and $\mathrm{OH}^{-}$ions were significantly increased after the treating process. It can be reasonably assumed that the existence of $\mathrm{NaHCO}_{3}$ was the source of the $\mathrm{OH}^{-}$ions in the solution. Researchers had claimed the relationship between superhydrophilicity and the amount of these negative charged ions. For instance, superhydrophilicity of $\mathrm{NaOH}$-treated SLA surfaces was indicated to be led by deprotonation and ion exchange of hydroxylgroups on the $\mathrm{TiO}_{2-x}$ surfaces [16]. Moreover, many studies demonstrated that the improvement of surface hydrophilicity was caused by forming of new oxygen-containing groups on the surface, such as $-\mathrm{OH}$ and $-\mathrm{OOH}$, for these groups are hydrophilic [30]. Therefore, by concluding from comparing this study with other related literatures while taking the mild conditions of $\mathrm{NaHCO}_{3}$ treatment protocol into account, one might assume that the formation of $\mathrm{TiO}_{2-x}$ bound $\mathrm{OH}$ and $\mathrm{OH}^{-}$ions on Ti surfaces is one of the major chemical 
transformations for the presented $\mathrm{NaHCO}_{3}$ treatment of $\mathrm{Ti}$ specimens. Also, it should be noticed that the results of SEM and roughness measurement in this study showed that there was no physical change in microstructure of the Ti specimens after $\mathrm{NaHCO}_{3}$ treatment.

4.3. Protein Adsorption. Fibronectin was tested in this study. Generally, fibronectin exists as a protein dimer and it can be discovered in 2 fundamental forms: soluble (component of blood plasma and other fluids) and insoluble (component of the extracellular matrix of various tissues) [31]. As a major adhesion protein of the extracellular matrix, it binds to membrane-spanning receptors (i.e., integrin) and to extracellular components [32]. Among many extracellular matrix proteins, fibronectin is an important protein that can contribute some insight into osteoblast cell differentiation, cellcell interactions, and cell-matrix interactions [33]. Therefore, this protein was chosen to be involved in this study.

An osteoblast adhesion process consists of protein adsorption, cell interaction with the adsorbed proteins, cell attachment, and spreading on implant surfaces. This process plays an essential part of osseointegration [34].

Observing from Figure 8, the fluorescence intensity of $\mathrm{NaHCO}_{3}$-treated specimens was significantly higher than untreated specimens, indicating that more fibronectin was adsorbed on hydrophilic $\mathrm{NaHCO}_{3}$-treated specimens. This result agrees with some previous researches, which showed increased protein adsorption on hydrophilic specimens [3537]. Protivínský et al. described continuously increasing fibronectin adsorption on highly hydrophilic surfaces treated by a high-temperature and high-concentration $\mathrm{NaOH}$ solution [35]. Milleret et al. found $\mathrm{NaOH}$ treated SLA Ti surfaces to partially heparinize whole human blood. Unstructured and discontinuous fibrinogen aggregates were observed on untreated group in their study, while a much denser mesh of fibrin fibers was recorded on $\mathrm{NaOH}$ treated group [15]. The initial binding of proteins relies on the physicochemical features of a surface, such as roughness, surface energy, and chemical composition [36, 38, 39]. The topographic features of the surfaces have particular consequences in terms of hydrophilicity. Before $\mathrm{NaHCO}_{3}$ treatment, microrough SLA Ti discs were hydrophobic. According to the CassieBaxter regime [3], the presence of air entrapment in the micropores on hydrophobic surfaces resists the contact of the solution which could have a negative effect of the surface contact area in the rough surfaces, inhibiting protein adsorption [39]. After $\mathrm{NaHCO}_{3}$ treatment, superhydrophilic SLA Ti surfaces were supposed to be filled with protein solution, which can increase the surface-protein contact area. Moreover, it is assumed by Rupp et al. that a higher surface free energy initiates the adsorption of proteins [11]. Supporting this assumption, studies have proved that SLA Ti specimens stored freshly in sodium chloride solution, as mentioned above, which exhibits a higher surface free energy, do significantly increase human plasma fibronectin adsorption [37]. Therefore, it is reasonable to consider that, after $\mathrm{NaHCO}_{3}$ treatment, higher surface free energy of SLA Ti surfaces also facilitated the adsorption of fibronectin.
However, some previous studies showed that proteins tended to be adsorbed more extensively on hydrophobic surfaces [ 40 , 41]. This disagreement between the protein adsorption results from different studies may be caused by the usage of a variety of proteins with different molecular properties and surfaces with different topographic features, while it still needs further research to investigate how protein types, surface roughness, and wettability affect protein adsorption.

The distribution feature of fibronectin on untreated and $\mathrm{NaHCO}_{3}$-treated surfaces was revealed with a significant difference in this study. The reasons behind this difference were also worth discussion. It is claimed that ionic strength of local environment takes active part in determining fibronectin's molecular shape. That is to say, with increased ionic strength, fibronectin may display a more stretched distribution form [38]. In this study, the fibronectin spread to a more extended form on $\mathrm{NaHCO}_{3}$ discs, which were supposed to possess a higher ionic strength compared to untreated discs.

The adsorption of proteins on implant surfaces is essential because it can affect the early biological response of the surrounding microenvironment, which has an effect on the healing process as well as the final clinical outcomes of implants $[42,43]$. Rivera-Chacon et al. proved this point by finding that increased cell attachment and proliferative capacity occurred on titanium surfaces with more fibronectin adsorption [44]. It was also evidenced that the alkali-treated implants on acidetched surfaces are able to promote secondary stability in an earlier phases of implant site healing in dog experiments compared with the untreated implants [45]. Moreover, Held et al. recorded the results of alkali treated blasted and acidetched implants in a series of clinical cases [46]. In their study, a number of blasted and acid-etched implants were placed in a group of patients with compromised bone density. Concluding from these experiments, the implants exhibited good stability quotient as well as vertical bone volume for at least 1 year after loading.

4.4. General Discussion on Modification of Ti Surface by Alkali Treatment. As $\mathrm{NaHCO}_{3}$ solution is weakly alkaline, Ti surfaces treated with $\mathrm{NaHCO}_{3}$ solution are expected to be able to generate similar effects to ones treated with $\mathrm{NaOH}$ solution. The results of hydrophilicity and physicochemical changes in this study were similar to those treated with $\mathrm{NaOH}$ solution [16]. However, some reports claimed that osteogenic differentiation of osteoprogenitor cells could be affected adversely by excessive alkalinization in the microenvironment of tissue-engineered constructs. Monfoulet et al. measured the range of usable $\mathrm{pH}$ values for alkalis with culture of bone marrow-derived mesenchymal stem cells (hBMSC). They have observed that there was no cell proliferation at $\mathrm{pH} 8.85$ and there were dead cells at $\mathrm{pH}$ 9.37. In contrast, cell proliferation was uninfluenced by alkaline that has a $\mathrm{pH}$ less than 8.27 [47]. Compared to $0.05 \mathrm{M} \mathrm{NaOH}(\mathrm{pH}$ 12.7), $1 \mathrm{M} \mathrm{NaHCO}_{3}$ solution ( $\mathrm{pH} 8.1$ ) has a $\mathrm{pH}$ value closer to the one of human body fluid ( $\mathrm{pH}$ 7.35-7.45). In addition, $\mathrm{HCO}_{3}{ }^{-}$is one of the buffer components in blood and body fluid. $\mathrm{NaHCO}_{3}$ is considered to be more suitable for this application because of its relatively weak alkalinity and ease 
of preparation. Thus, the authors proposed an assumption that $\mathrm{NaHCO}_{3}$ solution may be a more optimized alternative to $\mathrm{NaOH}$ solution for the application of dental implants. To examine this hypothesis, future efforts are required.

Further researches should be proposed to firstly evaluate other characteristics of $\mathrm{NaHCO}_{3}$-treated SLA Ti surfaces, such as blood component adhesion, cell adhesion, osseointegrative potential, and influences on bone formation. Further, as stated above, differences in the biocompatibility of $\mathrm{NaHCO}_{3}$ and $\mathrm{NaOH}$ solution should be evaluated. Lastly, the authors believe it is also worth to examine that, apart from $\mathrm{NaOH}$ and $\mathrm{NaHCO}_{3}$ solution, whether other kinds of alkaline solution are suitable for being applied in similar $\mathrm{Ti}$ surface treatments.

\section{Conclusions}

This study describes and evaluates a novel, simple, and convenient method to enhance hydrophilicity of Ti surfaces with $\mathrm{NaHCO}_{3}$ solution. It was discovered that superhydrophilicity of SLA Ti surfaces can be obtained by reversible deprotonation and ion exchange processes. In addition, increased protein adsorption on $\mathrm{NaHCO}_{3}$-treated specimens was also observed and evaluated. In conclusion, this $\mathrm{NaHCO}_{3}$ treatment is a reliable method for enhancing the hydrophilicity and protein adsorption of SLA Ti surfaces. It was also proposed that due to the simplicity and biocompatibility of $\mathrm{NaHCO}_{3}, \mathrm{NaHCO}_{3}$ treatment might be considered as a clinically viable strategy to render superhydrophilicity to $\mathrm{Ti}$ specimens in the site of implantation without requirements for modifying manufacturing or storage methods of the implants. The influences on a Ti surface's cell adhesion, cell proliferation, differentiation, and so forth after $\mathrm{NaHCO}_{3}$ treated will be addressed in our following studies. Moreover, the effects of $\mathrm{NaHCO}_{3}$ treatment on osseointegration should also be evaluated in future researches.

\section{Conflict of Interests}

The authors claim no conflict of interests.

\section{Authors' Contribution}

Shengnan Jia and Yu Zhang contributed equally to this work.

\section{Acknowledgments}

This study was supported by a grant from the National Basic Research Program of China (973 Program, 2012CB933900). Titanium specimens were provided by Wego (Wego Jericom Biomaterials Co., Weihai, China). Technical assistance of engineer Mr. Jishu Yin (Wego Jericom Biomaterials Co., Weihai, China) is gratefully acknowledged.

\section{References}

[1] F. J. Gil, N. Manzanares, A. Badet, C. Aparicio, and M.-P. Ginebra, "Biomimetic treatment on dental implants for shortterm bone regeneration," Clinical Oral Investigations, vol. 18, no. 1, pp. 59-66, 2014.

[2] Y. Förster, C. Rentsch, W. Schneiders et al., "Surface modification of implants in long bone," Biomatter, vol. 2, no. 3, pp. 149$157,2012$.

[3] F. Rupp, R. A. Gittens, L. Scheideler et al., "A review on the wettability of dental implant surfaces I: theoretical and experimental aspects," Acta Biomaterialia, vol. 10, no. 7, pp. 2894-2906, 2014.

[4] K. Anselme, M. Bigerelle, B. Nol, A. Iost, and P. Hardouin, "Effect of grooved titanium substratum on human osteoblastic cell growth," Journal of Biomedical Materials Research, vol. 60, no. 4, pp. 529-540, 2002.

[5] A. Canabarro, C. G. Paiva, H. T. Ferreira et al., "Short-term response of human osteoblast-like cells on titanium surfaces with micro- and nano-sized features," Scanning, vol. 34, no. 6, pp. 378-386, 2012.

[6] J. H. Park, C. E. Wasilewski, N. Almodovar et al., "The responses to surface wettability gradients induced by chitosan nanofilms on microtextured titanium mediated by specific integrin receptors," Biomaterials, vol. 33, no. 30, pp. 7386-7393, 2012.

[7] R. A. Gittens, R. Olivares-Navarrete, A. Cheng et al., "The roles of titanium surface micro/nanotopography and wettability on the differential response of human osteoblast lineage cells," Acta Biomaterialia, vol. 9, no. 4, pp. 6268-6277, 2013.

[8] D. Buser, N. Broggini, M. Wieland et al., "Enhanced bone apposition to a chemically modified SLA titanium surface," Journal of Dental Research, vol. 83, no. 7, pp. 529-533, 2004.

[9] C. Eriksson, H. Nygren, and K. Ohlson, "Implantation of hydrophilic and hydrophobic titanium discs in rat tibia: cellular reactions on the surfaces during the first 3 weeks in bone," Biomaterials, vol. 25, no. 19, pp. 4759-4766, 2004.

[10] M. M. Bornstein, P. Valderrama, A. A. Jones, T. G. Wilson, R. Seibl, and D. L. Cochran, "Bone apposition around two different sandblasted and acid-etched titanium implant surfaces: a histomorphometric study in canine mandibles," Clinical Oral Implants Research, vol. 19, no. 3, pp. 233-241, 2008.

[11] F. Rupp, L. Scheideler, N. Olshanska, M. de Wild, M. Wieland, and J. Geis-Gerstorfer, "Enhancing surface free energy and hydrophilicity through chemical modification of microstructured titanium implant surfaces," Journal of Biomedical Materials Research Part A, vol. 76, no. 2, pp. 323-334, 2006.

[12] H. Aita, N. Hori, M. Takeuchi et al., "The effect of ultraviolet functionalization of titanium on integration with bone," Biomaterials, vol. 30, no. 6, pp. 1015-1025, 2009.

[13] B. Feng, J. Weng, B. C. Yang, S. X. Qu, and X. D. Zhang, "Characterization of surface oxide films on titanium and adhesion of osteoblast," Biomaterials, vol. 24, no. 25, pp. 4663-4670, 2003.

[14] K. Duske, I. Koban, E. Kindel et al., "Atmospheric plasma enhances wettability and cell spreading on dental implant metals," Journal of Clinical Periodontology, vol. 39, no. 4, pp. 400-407, 2012.

[15] V. Milleret, S. Tugulu, F. Schlottig, and H. Hall, "Alkali treatment of microrough titanium surfaces affects macrophage/monocyte adhesion, platelet activation and architecture of blood clot 
formation," European Cells and Materials, vol. 21, pp. 430-444, 2011.

[16] S. Tugulu, K. Löwe, D. Scharnweber, and F. Schlottig, "Preparation of superhydrophilic microrough titanium implant surfaces by alkali treatment," Journal of Materials Science: Materials in Medicine, vol. 21, no. 10, pp. 2751-2763, 2010.

[17] S. Hamlet, M. Alfarsi, R. George, and S. Ivanovski, "The effect of hydrophilic titanium surface modification on macrophage inflammatory cytokine gene expression," Clinical Oral Implants Research, vol. 23, no. 5, pp. 584-590, 2012.

[18] M. Al Mustafa, H. Agis, H. D. Muller, G. Watzek, and R. Gruber, "In vitro adhesion of fibroblastic cells to titanium alloy discs treated with sodium hydroxide," Clinical Oral Implants Research, vol. 26, no. 1, pp. 15-19, 2015.

[19] J. L. Calvo-Guirado, A. J. Ortiz-Ruiz, B. Negri, L. López-Marí, C. Rodriguez-Barba, and F. Schlottig, "Histological and histomorphometric evaluation of immediate implant placement on a dog model with a new implant surface treatment," Clinical Oral Implants Research, vol. 21, no. 3, pp. 308-315, 2010.

[20] B. Stadlinger, S. J. Ferguson, U. Eckelt et al., "Biomechanical evaluation of a titanium implant surface conditioned by a hydroxide ion solution," British Journal of Oral and Maxillofacial Surgery, vol. 50, no. 1, pp. 74-79, 2012.

[21] J. Pratten, J. Wiecek, N. Mordan et al., "Physical disruption of oral biofilms by sodium bicarbonate: an in vitro study," International Journal of Dental Hygiene, 2015.

[22] T. Ma, X. Ge, S. Jia, X. Jiang, Y. Zhang, and Y. Lin, “The influence of titanium surfaces treated by alkalis on macrophage and osteoblast-like cell adhesion and gene expression in vitro," RSC Advances, vol. 5, no. 99, pp. 81378-81387, 2015.

[23] E. McCafferty and J. P. Wightman, "Determination of the concentration of surface hydroxyl groups on metal oxide films by a quantitative XPS method," Surface and Interface Analysis, vol. 26, no. 8, pp. 549-564, 1998.

[24] F. Schwarz, M. Wieland, Z. Schwartz et al., "Potential of chemically modified hydrophilic surface characteristics to support tissue integration of titanium dental implants," Journal of Biomedical Materials Research Part B: Applied Biomaterials, vol. 88, no. 2, pp. 544-557, 2009.

[25] Z. Qu, X. Rausch-Fan, M. Wieland, M. Matejka, and A. Schedle, "The initial attachment and subsequent behavior regulation of osteoblasts by dental implant surface modification," Journal of Biomedical Materials Research Part A, vol. 82, no. 3, pp. 658668, 2007.

[26] G. Zhao, Z. Schwartz, M. Wieland et al., "High surface energy enhances cell response to titanium substrate microstructure," Journal of Biomedical Materials Research Part A, vol. 74, no. 1, pp. 49-58, 2005.

[27] J. Vlacic-Zischke, S. M. Hamlet, T. Friis, M. S. Tonetti, and S. Ivanovski, "The influence of surface microroughness and hydrophilicity of titanium on the up-regulation of TGF $\beta / \mathrm{BMP}$ signalling in osteoblasts," Biomaterials, vol. 32, no. 3, pp. 665671, 2011.

[28] A. Wennerberg and T. Albrektsson, "Effects of titanium surface topography on bone integration: a systematic review," Clinical Oral Implants Research, vol. 20, supplement 4, pp. 172-184, 2009.

[29] F. Rupp, L. Scheideler, D. Rehbein, D. Axmann, and J. GeisGerstorfer, "Roughness induced dynamic changes of wettability of acid etched titanium implant modifications," Biomaterials, vol. 25, no. 7-8, pp. 1429-1438, 2004.

[30] J. Lai, B. Sunderland, J. Xue et al., "Study on hydrophilicity of polymer surfaces improved by plasma treatment," Applied Surface Science, vol. 252, no. 10, pp. 3375-3379, 2006.

[31] S. Cei, D. Karapetsa, E. Aleo, and F. Graziani, "Protein adsorption on a laser-modified titanium implant surface," Implant Dentistry, vol. 24, pp. 134-141, 2015.

[32] M. Gorbahn, M. O. Klein, M. Lehnert et al., "Promotion of osteogenic cell response using quasicovalent immobilized fibronectin on titanium surfaces: introduction of a novel biomimetic layer system," Journal of Oral and Maxillofacial Surgery, vol. 70, no. 8, pp. 1827-1834, 2012.

[33] A. M. Moursi, C. H. Damsky, J. Lull et al., "Fibronectin regulates calvarial osteoblast differentiation," Journal of Cell Science, vol. 109, part 6, pp. 1369-1380, 1996.

[34] K. Anselme, "Osteoblast adhesion on biomaterials," Biomaterials, vol. 21, no. 7, pp. 667-681, 2000.

[35] J. Protivínský, M. Appleford, J. Strnad, A. Helebrant, and J. L. Ong, "Effect of chemically modified titanium surfaces on protein adsorption and osteoblast precursor cell behavior," International Journal of Oral and Maxillofacial Implants, vol. 22, no. 4, pp. 542-550, 2007.

[36] N. Hori, T. Ueno, H. Minamikawa et al., "Electrostatic control of protein adsorption on UV-photofunctionalized titanium," Acta Biomaterialia, vol. 6, no. 10, pp. 4175-4180, 2010.

[37] L. Scheideler, F. Rupp, M. Wieland, and J. Geis-Gerstorfer, "Storage conditions of titanium implants influence molecular and cellular interactions," Scientific Poster, 2005.

[38] D. E. MacDonald, B. Markovic, M. Allen, P. Somasundaran, and A. L. Boskey, "Surface analysis of human plasma fibronectin adsorbed to commercially pure titanium materials," Journal of Biomedical Materials Research, vol. 41, no. 1, pp. 120-130, 1998.

[39] W. Song and J. F. Mano, "Interactions between cells or proteins and surfaces exhibiting extreme wettabilities," Soft Matter, vol. 9, no. 11, pp. 2985-2999, 2013.

[40] P. Roach, N. J. Shirtcliffe, D. Farrar, and C. C. Perry, "Quantification of surface-bound proteins by fluorometric assay: comparison with quartz crystal microbalance and amido black assay," The Journal of Physical Chemistry B, vol. 110, no. 41, pp. 20572-20579, 2006.

[41] J. Zimmermann, M. Rabe, D. Verdes, and S. Seeger, "Functionalized silicone nanofilaments: a novel material for selective protein enrichment," Langmuir, vol. 24, no. 3, pp. 1053-1057, 2008.

[42] A. Mata, X. Su, A. J. Fleischman et al., "Osteoblast attachment to a textured surface in the absence of exogenous adhesion proteins," IEEE Transactions on Nanobioscience, vol. 2, no. 4, pp. 287-294, 2003.

[43] V. Grigoriou, I. M. Shapiro, E. A. Cavalcanti-Adam, R. J. Composto, P. Ducheyne, and C. S. Adams, "Apoptosis and survival of osteoblast-like cells are regulated by surface attachment," Journal of Biological Chemistry, vol. 280, no. 3, pp. 1733-1739, 2005.

[44] D. M. Rivera-Chacon, M. Alvarado-Velez, C. Y. AcevedoMorantes et al., "Fibronectin and vitronectin promote human fetal osteoblast cell attachment and proliferation on nanoporous titanium surfaces," Journal of Biomedical Nanotechnology, vol. 9, no. 6, pp. 1092-1097, 2013.

[45] J. Strnad, K. Urban, C. Povysil, and Z. Strnad, "Secondary stability assessment of titanium implants with an alkali-etched 
surface: a resonance frequency analysis study in beagle dogs," International Journal of Oral and Maxillofacial Implants, vol. 23, no. 3, pp. 502-512, 2008.

[46] U. Held, D. Rohner, and D. Rothamel, "Early loading of hydrophilic titanium implants inserted in low-mineralized (D3 and D4) bone: one year results of a prospective clinical trial," Head and Face Medicine, vol. 9, article 37, 2013.

[47] L.-E. Monfoulet, P. Becquart, D. Marchat et al., "The pH in the microenvironment of human mesenchymal stem cells is a critical factor for optimal osteogenesis in tissue-engineered constructs," Tissue Engineering Part A, vol. 20, no. 13-14, pp. 1827-1840, 2014. 

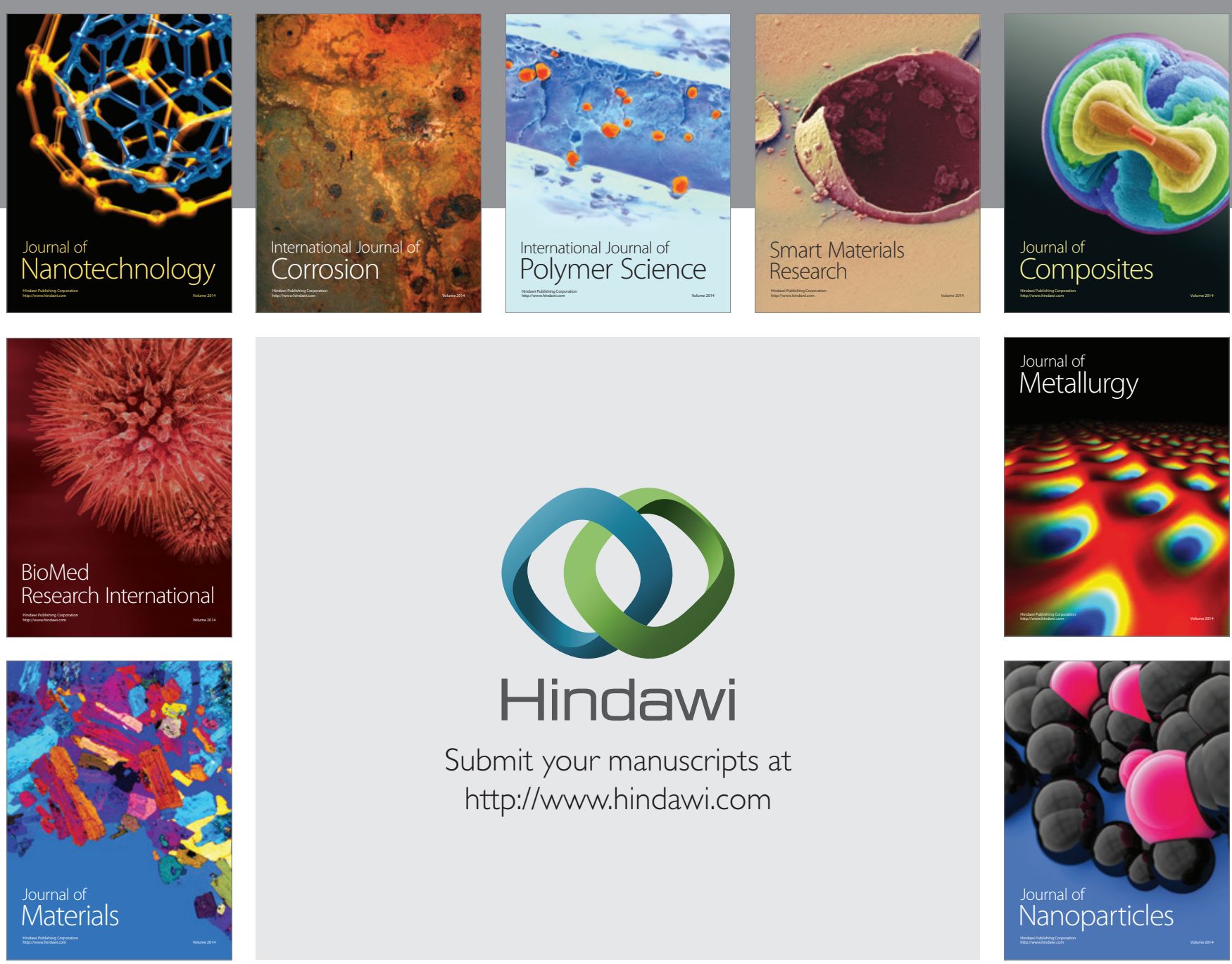

Submit your manuscripts at http://www.hindawi.com
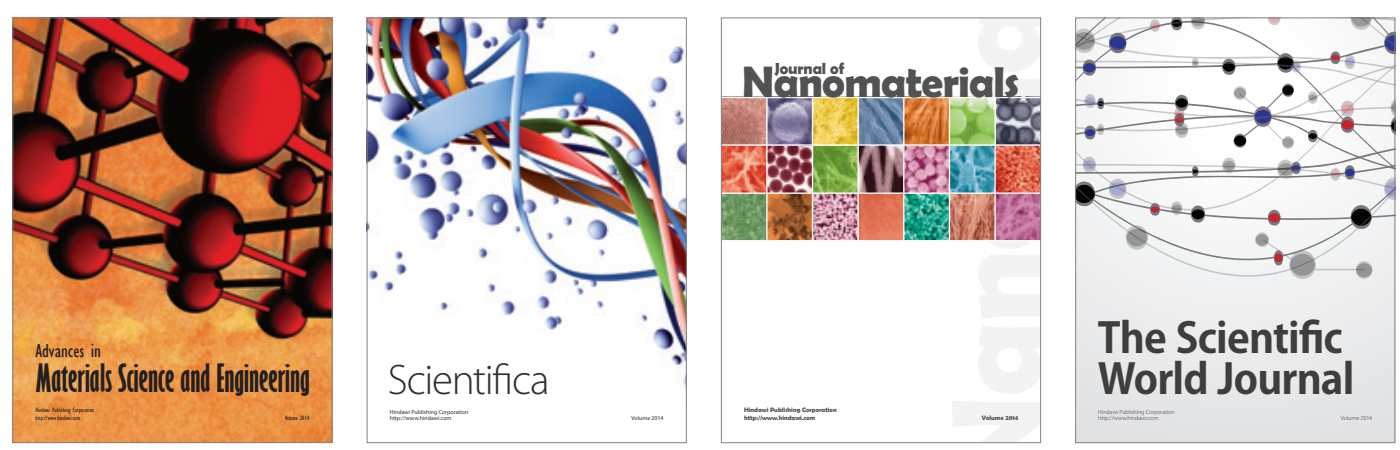

\section{The Scientific World Journal}
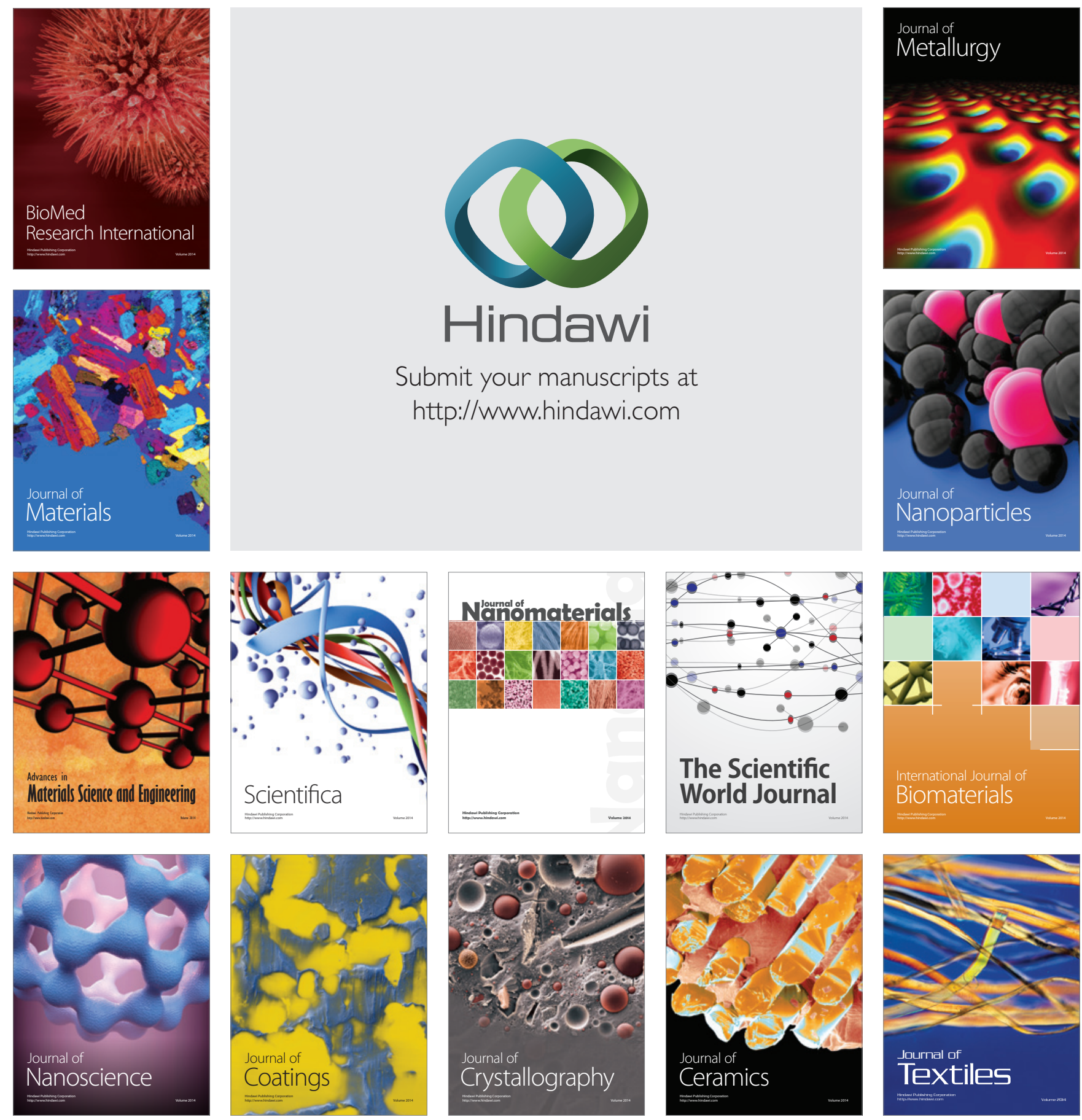